\title{
A Conversation with Leemor Joshua-Tor
}

\author{
INTERVIEWER: LARA SzEWCZAK \\ Senior Scientific Editor, Cell
}

\begin{abstract}
Leemor Joshua-Tor is the W.M. Keck Professor of Structural Biology at Cold Spring Harbor Laboratory and a Howard Hughes Medical Institute Investigator.
\end{abstract}

Lara Szewczak: You work on a very small protein, Asterix. Remind me what it does.

Dr. Joshua-Tor: We didn't know when we started. We only knew that it was picked up in these piRNA [piwiinteracting RNA] screens where both Greg Hannon's lab and Julius Brennecke's lab were looking for other factors that are involved in the piRNA pathway. This is one that was very clearly giving a strong phenotype, a strong effect. Looking at it, it didn't appear very interesting because it just had these two zinc fingers in it and then nothing much else to go on. But that's something we like to do. We like to go after things that are mysterious. So, we picked that one to try to figure out if we can - maybe using the structure - try to tease out some kind of information as to what exactly it does. We did know where in the pathway it works. We knew that it's in the nucleus. We knew that it doesn't affect piRNA biogenesis. It was pretty clear that it was affecting what's called the "effector" part of the pathway-probably the silencing step itself-but we didn't really know in molecular detail what it actually did.

Lara Szewczak: Now that you've got a handle on it, where do you see the study going?

Dr. Joshua-Tor: We came up with a model where we found that Asterix binds these tRNAs [transfer RNAs]. We're wondering now whether that really is happening. It appears to be the case, and our best guess is that it's binding to the primer binding sites on these retrotransposons because that's where tRNA fits into this whole game. There's a little bit of work still to do to figure out if that all looks good, but we're really excited about it to see if that's really happening.

Lara Szewczak: There are other RNAs that have tRNAlike elements to them. Your data showed a pretty specific size. Have you tried looking at larger things that may have similar structures? I know the model was built around tRNA because of the link to the retrotransposons, but have you thought about other options?

Dr. Joshua-Tor: We were pretty agnostic as to what it would be. It was copurifying with the protein initially when we first looked at it and found that it was a tRNA.
The way we expressed the protein was a mouse protein in this insect called armyworm - it's a moth — so we weren't sure that it was relevant at all. That's why we looked for what the mouse protein would pull out in mouse cells that have piRNAs, and in Drosophila in ovary cells that also are part of the pathway, to see if it's still doing that. It appears to pick up tRNAs very specifically. It's not fragments. Fragments are all over the place, but this appears to be a full tRNA.

Lara Szewczak: Is the protein restricted to germline?

Dr. Joshua-Tor: Yes, it appears so.

Lara Szewczak: You're a structural biologist. Crystallography is your bread and butter, but you needed to turn to a different approach. How did bringing in NMR [nuclear magnetic resonance] let you answer the question you wanted to?

Dr. Joshua-Tor: We don't shy away from other approaches. We use whatever fits. We got into cryo-EM [electron microscopy] and we're having a lot of fun with that as well. But this is a teensy little guy, so it was just natural to try to do it by NMR. Jon Ipsaro-who's really the hero of the story - wanted to learn how to do it himself, so we chose a collaborator that was nearby.

Lara Szewczak: What kinds of questions do you want to answer now about RNA that you haven't been able to do before because you didn't have crystals or another approach?

Dr. Joshua-Tor: There are a lot of things that you can now do with cryo-EM. You need to make a really good sample that's fairly clean, but it's not quite the same bar as when you want to actually crystallize it. Also, we have a little bit more leeway in terms of conformational flexibility of the molecules, whereas in crystallography you can't do it.

We have another system that we've been working - the TUTases [terminal uridylyl transferases]—with respect to their biogenesis and destruction of an important microRNA called let-7. We can now assemble these complexes and they might have conformational flexibility, but we don't have to cut off all the extra loops and things like

(C) 2019 Joshua-Tor. This article is distributed under the terms of the Creative Commons Attribution-NonCommercial License, which permits reuse and redistribution, except for commercial purposes, provided that the original author and source are credited. 
that. We can deal with it because you can computationally purify out the different complexes. It opened up a lot of possibilities for us, so we're interested in that. I started my career in RNA and RNA interference with Argonaute and that also factors into our studies, but the piRNA pathway is probably the most intriguing because there are a lot of factors that have been shown to be a part of this pathway. We know where they fit in and a little bit of what they do, but mechanistically how they do it, we don't. This is an opportunity for us to jump in and figure out some stuff that would be interesting.

Lara Szewczak: To be able to do cryo-EM, you essentially went back to school. What did you have to do to bring the technology on board?

Dr. Joshua-Tor: First of all, we had to get a microscope. Bruce Stillman, who is the president of Cold Spring Harbor, was very generous in raising the money to get the microscope. There are a lot of practical videos onlineabout $70 \mathrm{~h}$, at least - on the technique, which I watched. We started a cryo-EM course at Cold Spring Harbor, which I was a huge advocate for, and I was Student \#1 in the course. I just took it full on, practical and computational and everything, and people in my lab really bought into it. They're all really excited about it. We've been going to courses all around the world, and mostly just doing it and getting advice from people. It's really fun to-at this stage-learn something really new and so powerful, too.

Lara Szewczak: Are you actually going to be in the lab solving a structure, or do you want to be able to just advise?

Dr. Joshua-Tor: I want to be able to advise, to be critical of what people are doing, because if I don't know all the little issues that come along then I don't think I'd be able to do either of those. I wish I could work on the structure, but I don't think the people in my lab would even let me do it.

Lara Szewczak: One of the issues about cryo-EM that's different from crystallography is that the community hasn't yet agreed on set standards, like all the statistics in crystallography that let your peers assess the quality of the structure. Do you think that cryo-EM is going to get to a point where there are those kinds of agreed upon metrics, or just because of the nature of the technique is it always going to be "descriptive?"

Dr. Joshua-Tor: I think it's just a matter of time and development. When I started with crystallography we also didn't have a lot of the quality controls that we have today. We had more primitive ones, but now we're very careful about it. We have all these ways of quality control in assessing structure. It's going to happen faster in cryoEM, not only because there's more people - the computational techniques are a lot more sophisticated and all that - but also all of us crystallographers are jumping into cryo-EM, so we bring these traditions with us. I think they'll have no choice. This is all going to be developed, and I think not in too long of a time.
Lara Szewczak: What are the kinds of questions where crystallography is going to remain the premier technique, and how are those distinct from the kinds of questions you use cryo-EM or NMR for?

Dr. Joshua-Tor: NMR is very good for looking at dynamics, which we really can't do at all in crystallography, and we can't do as well in cryo-EM. Crystallography is really good at getting very high-resolution structures. The field of drug design and drug development is still going to enjoy what crystallography has to do. It's true that in cryoEM we're able to look at smaller and smaller things at very high resolution, but those are things that are very well behaved, etc. You also need "well-behaved" samples for crystallography, but it's still so powerful and the technique is so streamlined now - especially for small things and for looking at complexes with drugs - that I think that it still has a place. We can do small things like Argonaute on the cryo-EM, but we know how to crystallize it and it looks so good, so why make our lives more complicated if we can use crystallography?

Lara Szewczak: How does understanding the biology integrate into the process of understanding the structure?

Dr. Joshua-Tor: It's just practical, because we have to know what to do to our sample to coax it in a way that it would like to be in. In many cases it's adding the right partners, whether it's small ligands, but importantly, also big partners. If we don't understand how it associates with them and what pieces of RNA it likes to look at and things like that, our job would be much harder. There's a fantastic description in Barry Werth's book called The Billion-Dollar Molecule where he says for crystallization-but I think it's for every sample - that you have to bathe it in the right "amniotic fluids" so that they will "feel good" about themselves.

Lara Szewczak: Are there questions that you wanted to ask about biological systems in the past that you couldn't get around that you now think about going back to?

Dr. Joshua-Tor: With the discussion we were just having with cryo-EM, yes. We've been working on a helicase where it assembles into different states, and each state controls a different part of the maturation into a helicase, from binding double-stranded DNA to melting doublestranded DNA to translocating on DNA. We could get at a couple of these states before, but we couldn't get at one crucial one because we couldn't make enough and we thought it might be too unstable and just not amenable for crystallization. Now, we're going for it. This is part of the piRNA pathway, actually. That's one example, but we actually have a couple of these complexes that are bigger and unwieldy in our freezer that we had very small amounts of and we didn't know what to chop off that would give us more expression that we're taking out of the freezer now. That's fun.

Lara Szewczak: What are the things that students should be aware of when they're getting into structural biology now? 
Dr. Joshua-Tor: To me, I don't know how you can live without it, because seeing exactly what things look like is so informative to how they work. That happened very clearly in several cases in my career. I just can't live with blobs in a cartoon. It just doesn't do it for me. You can go back to the blobs, but then you're informed by what the structures are telling you about how things actually work. I'm a chemist at heart and by training, so I always go back to the exact mechanisms. There are a lot of people out there still where that really floats their boat. That's their cup of tea, so they'll come. Also, there's such an aesthetic about structural biology and the techniques that are producing these wonderful images. There's such an aesthetic about the molecules themselves that I hope people are still excited about it. 


\section{$\$_{\text {CSH\& }}^{\infty}$ Cold Spring Harbor Symposia SYMPOSIA on Quantitative Biology}

\section{A Conversation with Leemor Joshua-Tor}

Cold Spring Harb Symp Quant Biol published online February 18, 2020

Access the most recent version at doi:10.1101/sqb.2019.84.039388

$\mathbf{P}<\mathbf{P} \quad$ Published online February 18, 2020 in advance of the print journal.

Creative This article is distributed under the terms of the

Commons http://creativecommons.org/licenses/by-nc/4.0/, which permits reuse and

License redistribution, except for commercial purposes, provided that the original author and source are credited.

Email Alerting

Receive free email alerts when new articles cite this article - sign up in Service the box at the top right corner of the article or click here.

Advance online articles have been peer reviewed and accepted for publication but have not yet appeared in the paper journal (edited, typeset versions may be posted when available prior to final publication). Advance online articles are citable and establish publication priority; they are indexed by PubMed from initial publication. Citations to Advance online articles must include the digital object identifier (DOIs) and date of initial publication.

To subscribe to Cold Spring Harbor Symposia on Quantitative Biology go to: http://symposium.cshlp.org/subscriptions 